\title{
Changes in Inflammatory Cytokines in Saliva after Non-Surgical Periodontal Therapy: A Systematic Review and Meta-Analysis
}

\author{
Ji-Youn Kim ${ }^{1}$ and Han-Na Kim ${ }^{2, *} * \mathbb{D}$ \\ 1 Department of Dental Hygiene, College of Health Science, Gachon University, Incheon 21936, Korea; \\ hoho6434@gachon.ac.kr \\ 2 Department of Dental Hygiene, College of Health and Medical Sciences, Cheongju University, \\ Cheongju 28503, Korea \\ * Correspondence: hnkim@cju.ac.kr; Tel.: +82-43-229-8373
}

Citation: Kim, J.-Y.; Kim, H.-N. Changes in Inflammatory Cytokines in Saliva after Non-Surgical Periodontal Therapy: A Systematic Review and Meta-Analysis. Int. J. Environ. Res. Public Health 2021, 18 194. https://doi.org/10.3390/ ijerph18010194

Received: 7 December 2020 Accepted: 25 December 2020 Published: 29 December 2020

Publisher's Note: MDPI stays neutral with regard to jurisdictional clai$\mathrm{ms}$ in published maps and institutional affiliations.

Copyright: (C) 2020 by the authors. Licensee MDPI, Basel, Switzerland. This article is an open access article distributed under the terms and conditions of the Creative Commons Attribution (CC BY) license (https:// creativecommons.org/licenses/by/ $4.0 /$ )

\begin{abstract}
To determine the diagnostic value of inflammatory cytokines in periodontal disease, we performed a systematic review of the changes in inflammatory cytokines after non-surgical periodontal therapy and a meta-analysis of the utility of interleukin (IL)- $1 \beta$ and matrix metalloproteinase (MMP)-8 as salivary biomarkers. All available papers published in English until 20 August 2020, were searched in the MEDLINE and EMBASE databases. Population, intervention, comparison, and outcome data were extracted from the selected studies, and the roles of IL- $1 \beta$ and MMP- 8 were assessed in a meta-analysis. Eleven studies, including two meta-analyses, were assessed in the systematic review. Biomarkers showing high levels in periodontal disease were salivary IL-1 $\beta$, IL-4, IL-6, MMP-8, and tissue inhibitor of matrix metalloproteinases (TIMP)-2, and those in the controls were tumor necrosis factor (TNF)- $\alpha$, IL-10, IL-17, and IL-32. Biomarkers that decreased after scaling and root planning (SRP) and oral hygiene instruction (OHI) in periodontitis patients were IL- $1 \beta$, MMP-8, MMP-9, prostaglandin E2 ( $\mathrm{PGE}_{2}$ ), and TIMP-2. The pooled standardized mean difference of IL-1 $\beta$ and MMP-8 was -1.04 and 35.90, respectively, but the differences between periodontitis patients and healthy controls were not significant. Although the changes in salivary IL-1 $\beta$ and MMP-8 levels after non-surgical periodontal therapy were not significant, salivary cytokines could be used to confirm the effect of periodontal therapy or diagnose periodontal disease.
\end{abstract}

Keywords: periodontitis; scaling; saliva; cytokine; biomarker

\section{Introduction}

Periodontal disease is the most common bacterial infection worldwide. It occurs mainly in adults, and a large population of people aged 30 years or older show this disease [1]. The prevalence of periodontal disease is known to increase with age in the elderly population aged 65 years or older [2]. Periodontal disease is divided into two stages. The initial stage is characterized by gingivitis, which manifests as gingival swelling and redness with bleeding. As the condition progresses to periodontitis, the second stage, inflammation, is not confined to the gingiva and spreads to the periodontal tissue, including the periodontal ligament and alveolar bone. Periodontitis is classified into mild, moderate, and severe according to the progression status [3]. Advanced periodontitis can cause tooth mobility or even tooth loss due to severe alveolar resorption [4]. Gingivitis is confined to the gingiva, which can be returned to the healthy state by appropriate oral health management, while periodontitis represents an irreversible stage that is difficult to restore to the previous healthy state since the inflammation has spread to the alveolar bone and periodontal tissue [3,5]. Thus, early diagnosis of periodontitis is very important to prevent the loss of healthy teeth due to advanced periodontitis. Furthermore, periodontitis is a risk factor for the development of osteonecrosis of the jaws in patients taking antiresorptive 
drugs [6]. Dental professionals can differentiate patients with advanced periodontitis based on clinical diagnostic criteria, such as probing depth, attachment loss, bleeding on probing, and radiographic findings. However, diagnosis of periodontal disease at its incipient or early stages on the basis of clinical diagnostic criteria is difficult. Accordingly, multiple trials have been conducted for early diagnosis of periodontal disease.

Saliva offers the advantage of easy and noninvasive collection and can be used as the gold standard for early detection and monitoring of periodontitis $[7,8]$. Saliva contains various factors, such as enzymes, growth factors, hormones, immunoglobulins, and bacteria and their products, through which oral health status can be assessed [9]. Thus, there is growing interest in biomarker studies using saliva for the selection and diagnosis of oral diseases [7]. In particular, salivary biomarkers such as inflammatory cytokines, including interleukins (ILs) and tumor necrosis factors (TNFs) [10-12], enzymes [13-17], and growth factors $[18,19]$, have been verified for their usefulness in the diagnosis and monitoring of diseases. Many studies have attempted to identify the key salivary biomarkers for the diagnosis and selection of periodontal diseases. In particular, changes in inflammatory cytokines and enzymes have been investigated as candidate salivary biomarkers for the diagnosis of periodontal disease. Periodontitis as an inflammatory disease has been known to increase the levels of proinflammatory cytokines, including IL- $1 \alpha$, IL- $1 \beta$, IL- 6 , and TNF$\alpha$ [20-27]. In addition, various enzymes, such as matrix metalloproteinases (MMPs) and inflammatory mediators, are secreted by neutrophils $[22,26,28,29]$. The levels of salivary biomarkers, including IL-1, IL-6, and MMP-8, are reported to be significantly increased in patients with periodontitis in comparison with healthy controls [30]. Thus, this study aimed to perform a systematic review and meta-analysis for the utility of salivary biomarkers as a diagnostic tool for distinguishing patients with periodontitis and healthy controls, by examining the changes in salivary IL- $1 \beta$ and MMP-8 levels before and after non-surgical periodontal therapy.

\section{Materials and Methods}

The authors followed criteria established in the Preferred Reporting Items for Systematic Reviews and Meta-Analyses (PRISMA) guidelines for this review [31], and it aimed to analyze the salivary cytokine content in relation to periodontal disease and evaluate alterations in salivary biomarker levels in relation to periodontal disease after non-surgical periodontal therapy. The target search strategy was prepared on the basis of the research question; the articles to be analyzed were selected in accordance with the inclusion and exclusion criteria of the research; and the data were extracted and analyzed after quality evaluation.

\subsection{Search Strategy}

The MEDLINE and EMBASE databases were searched using relevant Medical Subject Headings (MeSH) or EMTREE terms to identify the relevant articles. The search terms confirmed by the preliminary survey were as follows: "(gingivitis OR periodontitis OR periodontal disease) AND saliva NOT caries". Secondary searches were performed in EMBASE using the EMTREE terms "Gingivitis OR periodontitis OR periodontal disease AND saliva NOT caries" and "periodontitis" as the free text term. Using these search terms, we searched for all academic papers published until 20 August 2020, and identified those with full-text availability. The reference lists of the eventually included papers were hand-searched to identify additional relevant studies. The list of materials extracted from each site was collected in a bibliographic program; duplicate data were excluded; and the selection process was performed by applying the inclusion and exclusion criteria. Except for the cases in which the language could not be interpreted (i.e., the paper was not in English or Korean) or in cases where the full text could not be verified, all assessments were conducted by two researchers, and when the researchers' initial assessments were different, the final decision was based on a consensus after several discussions. 


\subsection{Inclusion and Exclusion Criteria}

Studies that met the following criteria were included: (a) adult participants aged 20 or older with no underlying systemic disease (population), (b) periodontal therapy or non-surgical periodontal therapy (interventions), (c) assessment of salivary cytokines related to periodontal disease was performed after treatment, and (d) a comparative study was performed between the levels of these markers before and after periodontal treatment (comparison and outcome). Exclusion criteria were as follows: studies that investigated the changes in salivary enzymes or proteins other than cytokines and MMPs and simple research studies instead of a laboratory study and secondary analysis studies.

\subsection{Quality Assessment of the Selected Studies}

The Risk of Bias in Nonrandomized Studies of Interventions (ROBINS-I) tool [32,33] was used to assess the study quality. Bias was evaluated as "yes", "probably yes", "probably no", "no", or "unclear". The risk of bias was evaluated as "low", "moderate", "serious", and "critical". The quality evaluation of the literature was conducted by two reviewers who independently read the original text. Differences in evaluation scores were discussed to reach a final agreed-upon consensus score.

\subsection{Population, Intervention, Comparison, and Outcome Data Extraction}

Population, intervention, comparison, and outcome (PICO) data were extracted from all the included studies. Additionally, information regarding the study design and source (author and year of publication), aim of the study, and the number of groups was collected. The total number of participants, age and sex ratio were assessed as part of the participants' characteristics. The duration of periodontal therapy and intervention details sufficient for replication were also assessed. The number of participants allocated to each group, summary data for each intervention, and control groups (as reported), including adverse events, were assessed.

\subsection{Outcome Measures and Statistical Analysis}

The effects of changes in salivary cytokine levels after non-surgical periodontal therapy were analyzed. The changes in the levels of salivary IL- $1 \beta$, MMP-8, MMP-9, and TNF- $\alpha$ before and after treatment were compared in 11 studies. Statistical homogeneity was tested. To test the statistical homogeneity of effect sizes, a chi-squared test of homogeneity was performed, and the inconsistency index $\left(\mathrm{I}^{2}\right)$ and $\mathrm{Q}$ statistics were determined. Treatment effect, measured as continuous data, was expressed as the mean difference (MD) with $95 \%$ confidence intervals for outcomes measured with the same outcome measurement instrument or as standardized mean difference (SMD) with 95\% confidence intervals when different measurement instruments were used in all the studies included. Continuous outcomes, such as salivary IL-1 $\beta$ and MMP- 8 levels, were analyzed and expressed as SMDs with $95 \%$ confidence intervals. $p$ values $<0.05$ for both sides were considered to be statistically significant. However, the publication bias did not suggest because the number of papers was less than 10 in the meta-analysis. Statistical analysis for the meta-analysis was performed using Comprehensive Meta-Analysis, v2.0 (Biostat, Englewood, NJ, USA).

\section{Results}

\subsection{Study Selection}

After full-text assessments, a total of nine studies that met the study objective were identified. By adding two manually searched papers, a total of 11 studies were finally included for this systematic review and meta-analysis (Figure 1). 


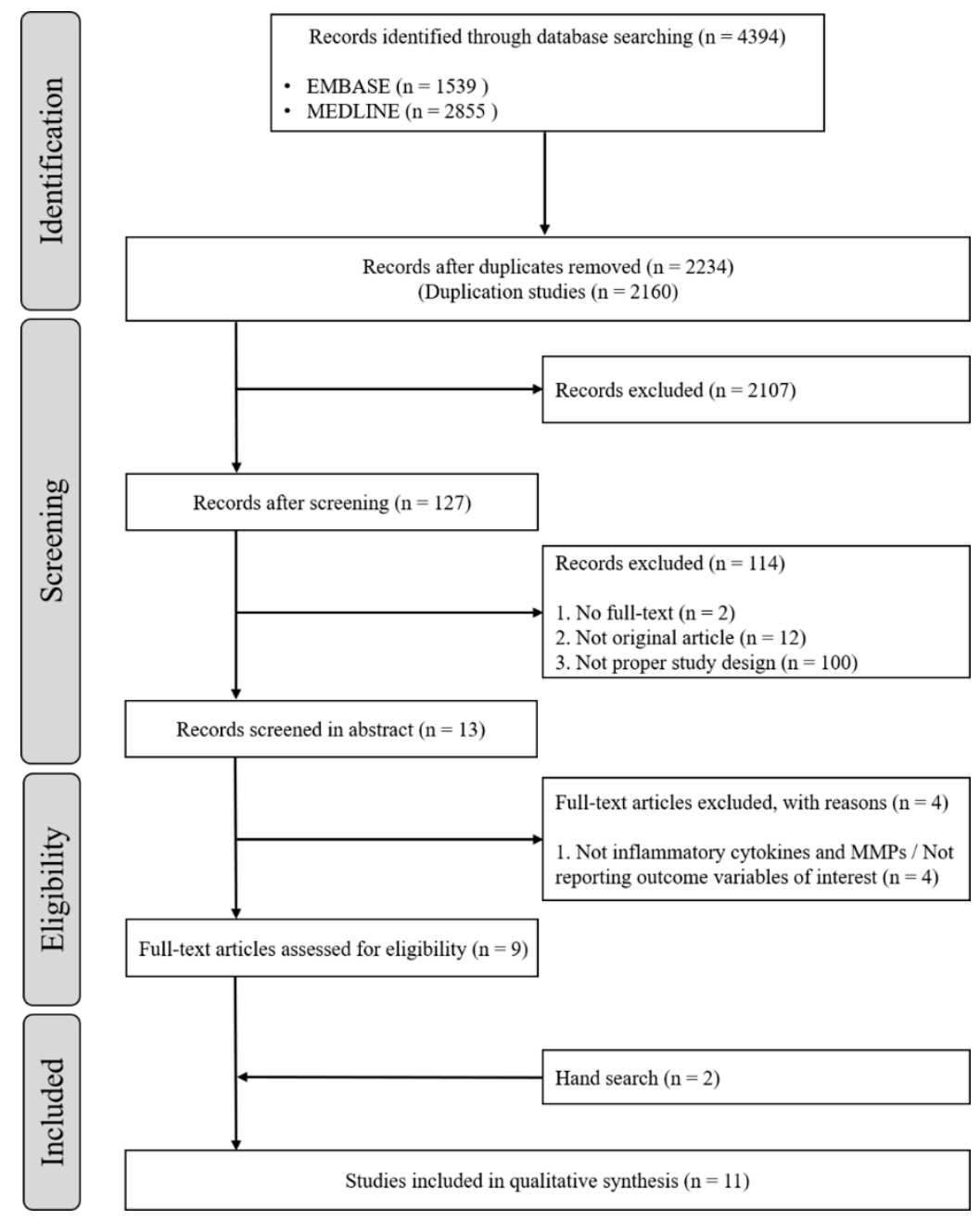

Figure 1. Flow diagram of the study selection process.

\subsection{Characteristics of the Included Studies}

The characteristics of participants are demonstrated in Table 1. All participants were healthy with no symptoms of systemic diseases at the time of the research and in the past. All participants had $\geq 16$ teeth, except third molars, and had no history of previous periodontal treatment. Pregnant and breastfeeding women were excluded. Participants were classified as having periodontal disease on the basis of evaluations of pocket depth (PD), clinical attachment loss (CAL), bleeding of probing (BOP), and alveolar bone loss in radiographs. Some studies classified periodontal disease into mild, moderate, and severe according to disease severity $[20,28]$. Participants with $\mathrm{PD} \leq 3 \mathrm{~mm}$, no CAL, no clinical signs of gingival inflammation, and minimal BOP scores were classified into the periodontally-healthy control group.

Table 1. Participant characteristics in the included articles.

\begin{tabular}{|c|c|c|}
\hline \multirow{2}{*}{ Author (Year) } & \multicolumn{2}{|c|}{ Participant Characteristics } \\
\hline & Patient Group & Control Group \\
\hline $\begin{array}{l}\text { Yoshie et al. } \\
\text { (2007) [34] }\end{array}$ & $\begin{array}{l}\text { - } \quad 38 \text { non-smokers and } 11 \text { smokers. } \\
\text { - The mean number of teeth present in all patients } \\
\text { was 26.4. } \\
\text { None of the participants had a history or current } \\
\text { signs of systemic disease. }\end{array}$ & $\mathrm{N} / \mathrm{A}$ \\
\hline
\end{tabular}


Table 1. Cont.

\begin{tabular}{|c|c|c|}
\hline \multirow{2}{*}{ Author (Year) } & \multicolumn{2}{|c|}{ Participant Characteristics } \\
\hline & Patient Group & Control Group \\
\hline $\begin{array}{l}\text { Sexton et al. } \\
(2011) \text { [22] }\end{array}$ & $\begin{array}{l}\text { - } \quad \geq 18 \text { erupted teeth. } \\
\text { - } \\
\text { pone of the participants had a history or current s } \\
\text { - } \quad \text { No pregnant or lactating patients were included in } \\
\quad<\text { Criteria for peri } \\
\text { - } \quad P D \geq 5 \mathrm{~mm}, \mathrm{CAL} \text { of } \geq 3 \mathrm{~mm} \text {, and BOP score of } \geq 2\end{array}$ & $\begin{array}{l}\text { igns of systemic disease and had not received } \\
\text { usly. } \\
\text { the study. } \\
\text { odontal disease> }\end{array}$ \\
\hline \multirow[b]{2}{*}{$\begin{array}{l}\text { Kinney et al. } \\
\text { (2011) [28] }\end{array}$} & $\begin{array}{l}\text { - } \quad \geq 20 \text { erupted teeth. } \\
\text { - } \quad \text { None of the participants had a history or current s } \\
\text { periodontal treatment or antibiotic therapy previo } \\
\text { - No pregnant or lactating patients were included in }\end{array}$ & $\begin{array}{l}\text { igns of systemic disease and had not received } \\
\text { usly. } \\
\text { the study. }\end{array}$ \\
\hline & $\begin{array}{l}\quad<\text { Criteria for periodontitis }> \\
\text { Mild: } \geq 4 \text { sites with evidence of radiographic } \\
\text { bone loss, } \leq 30 \% \text { sites with CAL }>3 \mathrm{~mm} \text {, } \\
\text { and } \geq 4 \text { sites with } \mathrm{PD}>4 \mathrm{~mm} \text {. } \\
\text { Moderate-severe: } \geq 4 \text { sites with evidence of } \\
\text { radiographic bone loss, }>30 \% \text { of sites with } \\
\text { CAL }>3 \mathrm{~mm} \text {, and } \geq 4 \text { sites with } \mathrm{PD}>4 \mathrm{~mm} \text {. }\end{array}$ & $\begin{array}{l}<\text { Criteria for periodontal health and gingivitis }> \\
\text { Periodontally-healthy: }<3 \mathrm{~mm} \text { of CAL, no PD of } \\
>4 \mathrm{~mm} \text {, no radiographic alveolar bone loss, and } \\
\text { BOP } \leq 20 \% \text {. } \\
\text { Gingivitis: }<3 \mathrm{~mm} \text { of CAL, no PD of }>4 \mathrm{~mm} \text {, no } \\
\text { radiographic alveolar bone loss, and } \mathrm{BOP}>20 \% \text {. }\end{array}$ \\
\hline \multirow[b]{2}{*}{$\begin{array}{l}\text { Kaushik et al. } \\
\text { (2011) [24] }\end{array}$} & $\begin{array}{l}\text { - Non-smoking. } \\
\text { - None of the participants had a history or current s } \\
\text { periodontal treatment or antibiotic therapy previo }\end{array}$ & $\begin{array}{l}\text { igns of systemic disease and had not received } \\
\text { usly. }\end{array}$ \\
\hline & $\begin{array}{l}\text { <Criteria for periodontitis }> \\
\text { Moderate-severe: } \leq 2 \text { teeth missing in each } \\
\text { quadrant, } \geq 30 \% \text { sites with } \mathrm{PD} \geq 4 \mathrm{~mm} ; \geq 20 \% \\
\text { sites with CAL }>2 \mathrm{~mm} ; \geq 30 \% \text { sites showing BOP; } \\
\text { and visible radiographic evidence of bone loss. }\end{array}$ & $\begin{array}{l}<\text { Criteria for periodontal health }> \\
\text { - }<10 \% \text { of sites with BOP, no sites with } \mathrm{PD} \geq 4 \mathrm{~mm} \text {, } \\
\text { no CAL }>2 \mathrm{~mm} \text {, and no visible radiographic } \\
\text { evidence of bone loss. }\end{array}$ \\
\hline
\end{tabular}

- Non-smoking; no pregnancy.

- None of the participants had a history or current signs of systemic disease and had not received periodontal treatment or antibiotic therapy previously.

Sánchez et al. <Criteria for periodontitis> <Criteria for periodontal health>

(2013) [20]

- $\quad$ Mild: $<2$ sites with $\mathrm{CAL} \geq 4 \mathrm{~mm}$ and $<2$ sites with $\mathrm{PD} \geq 5$.

- $\quad$ Moderate: $\geq 2$ sites with $\mathrm{CAL} \geq 4 \mathrm{~mm}$ and $\geq 2$ sites with $\mathrm{PD} \geq 5$.

- Absence of periodontal disease.

- $\quad$ Severe: $\geq 2$ sites with CAL $\geq 6 \mathrm{~mm}$ and $\geq 2$ sites with $\mathrm{PD} \geq 5$.

- $\quad \geq 20$ erupted teeth.

- Non-smoking (current or former smoker for $<10$ years); no pregnancy.

- None of the participants had a history or current signs of systemic disease and had not received

Meschiari et al. periodontal treatment or antibiotic therapy previously.

(2013) [29] <Criteria for periodontal disease $>$

- $\quad$ At least 2 teeth with $\mathrm{PD} \geq 5 \mathrm{~mm}, \mathrm{CAL} \geq 6 \mathrm{~mm}$ and visible radiographic evidence of bone loss.

\section{$<$ Criteria for periodontal health $>$}

- $\quad$ Absence of periodontal disease.

- Non-smoking.

- None of the participants had a history or current signs of systemic disease and had not received periodontal treatment or antibiotic therapy previously.

Prakasam et al.

(2014) [25]
$<$ Criteria for chronic periodontitis $>$

- $\quad$ Moderate to severe: $\geq 30 \%$ sites having $\geq 4 \mathrm{~mm}$ $\mathrm{CAL}$, severe clinical inflammation, and high BOP scores.
$<$ Criteria for periodontal health $>$.

- no CAL, no overt clinical signs of gingival inflammation, and minimal BOP scores. 
Table 1. Cont

\begin{tabular}{|c|c|c|}
\hline \multirow{2}{*}{ Author (Year) } & \multicolumn{2}{|c|}{ Participant Characteristics } \\
\hline & Patient Group & Control Group \\
\hline $\begin{array}{l}\text { Shyu et al. } \\
\text { (2015) [27] }\end{array}$ & $\begin{array}{l}\text { - } \quad \geq 16 \text { functional teeth. } \\
\text { - } \quad \text { Systemically healthy status. } \\
\quad<\text { Criteria for chronic periodontitis }> \\
\text { - } \quad \geq 6 \text { pockets with PD of }>5 \mathrm{~mm} \text {. } \\
\text { - } \quad \text { Nwo subgroups after treatment (scaling). } \\
\text { Nonprogress treatment group: differences in the } \\
\text { percentage of patients showing }>7 \mathrm{~mm} \text { PD } \\
\text { increase between the initial clinical treatment and } \\
\text { after the completion of } 4 \text { weeks of clinical } \\
\text { treatment. } \\
\text { - }\end{array}$ & $\mathrm{N} / \mathrm{A}$ \\
\hline \multirow{2}{*}{$\begin{array}{l}\text { Yang et al. } \\
(2016)[21]\end{array}$} & $\begin{array}{l}\text { - } \quad \geq 20 \text { natural teeth (including at least } 4 \text { molar teeth } \\
\text { - } \quad \text { Non-smoking; no pregnancy. } \\
\text { - } \\
\text { periodontal treatment or antibiotic therapy previo }\end{array}$ & $\begin{array}{l}\text { ns of systemic disease and had not received } \\
\text { sly. }\end{array}$ \\
\hline & $\begin{array}{l}\text { <Criteria for chronic periodontitis }> \\
\text { PD of } \geq 4 \mathrm{~mm} ; \mathrm{CAL} \text { of } \geq 2 \mathrm{~mm} \text {; alveolar bone } \\
\text { destruction of }>30 \% \text {. }\end{array}$ & $\begin{array}{l}<\text { Criteria for periodontal health }> \\
\text { - } \quad \text { PD of } \leq 3 \mathrm{~mm}, \mathrm{CAL} \text { of } \leq 1 \mathrm{~mm} \text {, and no sulcular } \\
\text { bleeding index. }\end{array}$ \\
\hline \multirow{2}{*}{$\begin{array}{l}\text { Öngöz et al. } \\
\text { (2017) [23] }\end{array}$} & $\begin{array}{l}\text { - } \quad \geq 20 \text { natural teeth. } \\
\text { - } \quad \text { Non-smoking; no pregnant and lactating patients } \\
\text { (periodontal and orthodontic) treatment or antibi }\end{array}$ & $\begin{array}{l}\text { vere included. } \\
\text { gns of systemic disease and had not received dental } \\
\text { tic therapy previously. }\end{array}$ \\
\hline & $\begin{array}{l}<\text { Criteria for chronic periodontitis }> \\
\text { - GI rating of }>1, \geq 6 \text { teeth with } \mathrm{PD} \text { of } \geq 5 \mathrm{~mm} \text {, and } \\
\text { BOP in at least two separate regions. }\end{array}$ & $\begin{array}{l}\quad<\text { Criteria for periodontal health }> \\
\text { - } \quad \mathrm{PD} \leq 3 \mathrm{~mm} \text {, a GI rating of zero, no indications of } \\
\mathrm{CAL} \text {, no visible radiographic evidence of bone } \\
\text { loss. }\end{array}$ \\
\hline $\begin{array}{l}\text { Rangbulla et al. } \\
\text { (2017) [26] }\end{array}$ & $\begin{array}{l}\quad<\text { periodontitis criteria }> \\
\text { - } \quad \geq 20 \text { teeth. } \\
\text { - } \quad \text { Non-smoking. } \\
\text { professional oral prophylaxis during the past } \\
12 \text { months or antibiotic therapy. } \\
\text { - } \quad \text { PD } \geq 5 \mathrm{~mm}, \mathrm{CAL} \geq 4 \mathrm{~mm} .\end{array}$ & $\begin{array}{l}\quad<\text { Criteria for periodontal health }> \\
\text { - } \quad \text { None of the participants had a history or current } \\
\text { signs of systemic disease. } \\
\text { No pregnant and lactating were included in this } \\
\text { study. }\end{array}$ \\
\hline
\end{tabular}

$\mathrm{BOP}$, bleeding on probing; $\mathrm{CAL}$, clinical attachment loss; $\mathrm{PD}$, pocket depth; GI, gingival index.

\subsection{Excluded Studies}

Most of the papers excluded from the final 11 were confirmed as a result of the enzyme in saliva [20] or other biomarkers other than cytokines in saliva [35-38]. The case of confirming the salivary proteome as a result [38], the case of confirming the salivary tissue inhibitor of matrix metalloproteinases (TIMPs), and MPO levels were also excluded [29].

The characteristics of studies published until 20 August 2020 that reported changes in salivary biomarkers between before and after SRP in patients with periodontal disease are summarized in Table 2. The included studies are summarized according to the participant characteristics and types of collected saliva and biomarkers. The mean age of participants in these studies varied from 34 to 61 years [24,27]. A total of 234 periodontally-healthy controls were identified after excluding two studies with no healthy control group, and the total number of patients with periodontal disease was 376 . There was no significant sexrelated difference in the number of participants in the studies [20-24,27,28]. Participants were classified as "periodontally-healthy" and those "with periodontal disease". The included studies could be divided into those that only included patients with periodontal 
disease $[22,27,34]$ and those that assessed both patients with periodontal disease and periodontally-healthy controls $[20,21,23-26,28,29]$. The studies that assessed periodontal disease patients alone included those that performed SRP and OHI for every participant and then compared the findings before and after the treatment [27,34]. Another study randomly divided periodontal disease patients into two groups and then compared the findings in both groups after providing SRP or OHI, respectively [22]. Shyu et al. [27] performed scaling for periodontal patients who were divided into two groups according to disease progression (non-progression and effective treatment group) and compared the findings for both groups. The studies involving both periodontal patients and periodontally-healthy controls performed SRP and OHI for periodontal patients and OHI only [20], OHI and prophylaxis $[25,28,29]$, or no treatment for the periodontally-healthy controls $[21,23,24]$. Rangbulla et al. [26] provided SRP and OHI to both periodontal patients and periodontallyhealthy controls. To identify the changes in biomarkers after SRP and OHI, most studies collected unstimulated saliva rather than stimulated saliva at 4 and 12 weeks after SRP and OHI. The inflammatory cytokines and enzymes used as salivary biomarkers were IL- $1 \alpha$, IL-1 $\beta$, IL-4, IL-6, IL-8, IL-10, IL-17, IL-32, TNF- $\alpha$, and TNF- $\beta$, PGE 2 , MMP-8 and MMP-9, macrophage inflammatory protein (MIP)- $1 \alpha$, and TIMP-2, among which IL- $1 \beta$, TNF- $\alpha$, MMP-8, and MMP-9 were most commonly used to verify the changes after SRP.

\subsection{Main Findings}

The changes in salivary biomarker levels after SRP and OHI are the main findings of these 11 studies. The biomarkers showing elevated levels in the baseline saliva of patients with periodontal disease were IL- $1 \beta$, IL-4, IL-6, MMP-8, and TIMP-2, while the control group showed high levels of TNF-a, IL-10, IL-17, and IL-32. The biomarkers that decreased after SRP and OHI in periodontitis patients were IL-1 $\beta$, MMP-8, MMP-9, PGE 2 , and TIMP-2. After SRP and OHI, TNF- $\alpha$ and IL-32 levels significantly decreased while IL-1 $\beta$, IL-10, and MMP-8 levels significantly increased in comparison with those in the control group. The level of IL-8 did not vary from baseline after OHI and SRP.

Among salivary biomarkers, IL-1 $\beta$ was associated with clinical indicators (PD, BOP, CAL, GI, and radiographic assessment). The sensitivity and specificity of predicting periodontitis on the basis of IL-1 $\beta$ and PGE2 levels were also reported.

Sanchez et al. [20] reported that in the mild periodontitis group, IL-1 $\beta$ did not increase, whereas PGE2 increased. In the moderate periodontitis group, both biomarkers significantly increased. In the severe disease group, these two biomarkers increased similar those of the moderate disease group. MMP- 8 correlated with change in $\mathrm{PD} \geq 4 \mathrm{~mm}$ and positive BOP. 
Table 2. Characteristics of the included articles.

\begin{tabular}{|c|c|c|c|c|c|c|c|c|c|c|c|}
\hline \multirow[b]{2}{*}{$\begin{array}{c}\text { Author } \\
\text { (year) }\end{array}$} & \multicolumn{4}{|c|}{ Patient Group } & \multicolumn{4}{|c|}{ Control Group } & \multirow[b]{2}{*}{$\begin{array}{l}\text { Sample } \\
\text { Collection }\end{array}$} & \multirow[b]{2}{*}{$\begin{array}{l}\text { Inflammatory } \\
\text { Cytokines }\end{array}$} & \multirow[b]{2}{*}{ Main Findings } \\
\hline & $\begin{array}{c}\text { Age } \\
\text { (years; Mean } \\
\pm \text { SD) } \\
\end{array}$ & $\underset{\text { (Male/Female) }}{\mathrm{N}}$ & Treatment & $\begin{array}{c}\text { Period (Saliva } \\
\text { Sampling after } \\
\text { Treatment) }\end{array}$ & $\begin{array}{c}\text { Age } \\
\text { (years; Mean } \\
\pm \text { SD) } \\
\end{array}$ & $\underset{\text { (Male/Female) }}{\mathbf{N}}$ & Treatment & $\begin{array}{c}\text { Period (Saliva } \\
\text { Sampling after } \\
\text { Treatment) }\end{array}$ & & & \\
\hline $\begin{array}{l}\text { Yoshie et al. } \\
\text { (2007) [34] }\end{array}$ & $\begin{array}{c}\text { CP: } 55.1 \pm \\
2.0\end{array}$ & $49(24 / 25)$ & SRP & $\begin{array}{l}\text { At baseline and } \\
4 \text { weeks }\end{array}$ & $\mathrm{N} / \mathrm{A}$ & N/A & $\mathrm{N} / \mathrm{A}$ & N/A & SWS & IL-1 & $\begin{array}{l}\text { IL-1A allele } 2 \text { non-carriers displayed a significant } \\
\text { decrease in salivary AST and ALT levels; the } \\
\text { carriers did not show any changes in the salivary } \\
\text { levels of the enzymes after scaling. }\end{array}$ \\
\hline $\begin{array}{l}\text { Sexton et al. } \\
\text { (2011) [22] }\end{array}$ & $\begin{array}{c}\text { CP: } 40.3 \pm \\
10.0\end{array}$ & $35(26 / 9)$ & SRP and OHI & $\begin{array}{l}\text { At } 0,16 \text {, and } \\
28 \text { weeks }\end{array}$ & $\begin{array}{c}\text { CP: } 47.3 \pm \\
8.8\end{array}$ & $33(21 / 12)$ & OHI & $\begin{array}{l}\text { At week } 0, \\
16 \text { and } 28\end{array}$ & UWS & $\begin{array}{l}\text { IL-1 } \beta, \text { IL- } 8 \\
\text { MMP- } 8 \\
\text { MIP- } 1 \alpha, \text { and } \\
\text { TNF- } \alpha\end{array}$ & $\begin{array}{l}\text { Baseline TNF- } \alpha \text { levels changed significantly at } \\
\text { both follow-up visits (16 and } 28 \text { weeks), } \\
\text { regardless of the treatment group. } \\
\text { IL-1 } \beta \text { and MMP-8 levels decreased significantly } \\
\text { from baseline }(p<0.04) \text { in the SRP group only. } \\
\text { MMP- } 8 \text { and MIP-1 } \alpha \text { levels were significantly } \\
\text { reduced in comparison with those in the } \\
\text { non-responders to treatment }(p=0.01,0.05 \\
\text { respectively). } \\
\text { In receiver-operating characteristic analyses, } \\
\text { MMP-8 produced the highest area under the } \\
\text { curve }(\geq 0.7 ; p=0.01) \text {. }\end{array}$ \\
\hline $\begin{array}{l}\text { Kinney et al. } \\
\text { (2011) [28] }\end{array}$ & $\begin{array}{l}\text { Mild CP: 54; } \\
\text { Moderate to } \\
\text { severe CP: } 50\end{array}$ & $\begin{array}{l}\text { Mild: } 24 \\
\text { (11/13); } \\
\text { Modertate to } \\
\text { Severe: } 20 \\
(7 / 13)\end{array}$ & SRP and OHI & $\begin{array}{l}\text { Bi-monthly over } \\
\text { a 12-month } \\
\text { period }\end{array}$ & $\begin{array}{l}\text { Periodontally- } \\
\text { healthy: } 46 \\
\text { Gingivitis: } 46\end{array}$ & $\begin{array}{l}\text { Periodontally- } \\
\text { healthy: } \\
15(9 / 6) \\
\text { Gingivitis: } \\
24(10 / 14) \\
\end{array}$ & $\begin{array}{l}\text { Prophylaxis } \\
\text { and OHI }\end{array}$ & $\begin{array}{l}\text { Bi-monthly over } \\
\text { a 12-month } \\
\text { period }\end{array}$ & UWS & $\begin{array}{l}\text { IL-1 } \beta \text {, } \\
\text { MMP-8, and } \\
\text { MMP-9 }\end{array}$ & $\begin{array}{l}\text { Moderate to severe periodontitis patients } \\
\text { demonstrated reduction of MMP- } 8 \text {, MMP-9, and } \\
\text { IL-1 } \beta \text { at } 12 \text { months in comparison with baseline } \\
\qquad(p<0.05) \text {. }\end{array}$ \\
\hline $\begin{array}{l}\text { Kaushik et al. } \\
\text { (2011) [24] }\end{array}$ & $\begin{array}{l}\text { Moderate-to- } \\
\text { severe CP: } \\
34.9 \pm 6.4\end{array}$ & $28(8 / 20)$ & SRP and OHI & $\begin{array}{l}\text { Before and } 1 \\
\text { month }\end{array}$ & $\begin{array}{l}\text { Periodontally- } \\
\text { healthy: } 33.6 \\
\quad \pm 4.1\end{array}$ & $24(9 / 15)$ & No treatment & $\begin{array}{l}\text { Before and } \\
1 \text { month }\end{array}$ & UWS & IL-1 $\beta$ & $\begin{array}{l}\text { IL-1 } \beta \text { levels in periodontitis patients reduced } \\
\text { significantly post-treatment but were still } \\
\text { significantly higher than the baseline values of } \\
\text { controls. } \\
\text { IL-1 } \beta \text { showed a significant positive correlation } \\
\text { with percentage probing depth, bleeding on } \\
\text { probing, gingival index, and periodontal index. }\end{array}$ \\
\hline $\begin{array}{l}\text { Sánchez et al. } \\
\text { (2013) [20] }\end{array}$ & $\begin{array}{c}\text { Mild } \\
\text { periodontitis: } \\
38.3 \\
\text { Moderate } \\
\text { periodontitis: } \\
41.6 \\
\text { Severe } \\
\text { periodontitis: } \\
46.8\end{array}$ & $\begin{array}{l}\text { Mild } 18(14 / 4) \\
\text { Moderate } 21 \\
(17 / 4) \\
\text { Severe } 20 \\
(14 / 6)\end{array}$ & SRP and OHI & At 3 months & $\begin{array}{l}\text { Periodontally- } \\
\text { healthy: } \\
34.3\end{array}$ & $15(10 / 5)$ & OHI & At 3 months & UWS & $\begin{array}{c}\text { IL- } 1 \beta \text { and } \\
\text { PGE }_{2}\end{array}$ & $\begin{array}{l}\text { IL-1 } \beta \text { and } \mathrm{PGE}_{2} \text { levels reduced significantly } \\
\text { post-treatment. } \\
\text { With a selected threshold of } 212 \mathrm{pg} / \mathrm{mL} \text {, salivary } \\
\text { IL1- } \beta \text { predicted periodontitis with } 78 \% \text { sensitivity } \\
\text { and } 100 \% \text { specificity. } \\
\text { With a selected threshold of } 121 \mathrm{pg} / \mathrm{mL} \text {, salivary } \\
\text { PGE }_{2} \text { predicted periodontitis with } 78 \% \text { sensitivity } \\
\text { and } 91 \% \text { specificity. }\end{array}$ \\
\hline
\end{tabular}


Table 2. Cont.

\begin{tabular}{|c|c|c|c|c|c|c|c|c|c|c|c|}
\hline \multirow[b]{2}{*}{$\begin{array}{l}\text { Author } \\
\text { (year) }\end{array}$} & \multicolumn{4}{|c|}{ Patient Group } & \multicolumn{4}{|c|}{ Control Group } & \multirow[b]{2}{*}{$\begin{array}{l}\text { Sample } \\
\text { Collection }\end{array}$} & \multirow[b]{2}{*}{$\begin{array}{l}\text { Inflammatory } \\
\text { Cytokines }\end{array}$} & \multirow[b]{2}{*}{ Main Findings } \\
\hline & $\begin{array}{c}\text { Age } \\
\text { (years; Mean } \\
\pm \text { SD) } \\
\end{array}$ & $\underset{\text { (Male/Female) }}{\mathrm{N}}$ & Treatment & $\begin{array}{l}\text { Period (Saliva } \\
\text { Sampling after } \\
\text { Treatment) }\end{array}$ & $\begin{array}{c}\text { Age } \\
\text { (years; Mean } \\
\pm \text { SD) }\end{array}$ & $\underset{\text { (Male/Female) }}{\mathbf{N}}$ & Treatment & $\begin{array}{l}\text { Period (Saliva } \\
\text { Sampling after } \\
\text { Treatment) }\end{array}$ & & & \\
\hline $\begin{array}{l}\text { Meschiari et al. } \\
\text { (2013) [29] }\end{array}$ & None & 19 (none) & SRP & $\begin{array}{c}\text { Before and after } \\
3 \text { months of } \\
\text { treatment }\end{array}$ & $\begin{array}{l}\text { Periodontally- } \\
\text { healthy: } \\
\text { none }\end{array}$ & 11 (none) & $\begin{array}{l}\text { OHI and } \\
\text { prophylaxis }\end{array}$ & $\begin{array}{c}\text { Before and after } \\
3 \text { months of } \\
\text { treatment }\end{array}$ & SWS & $\begin{array}{l}\text { MMP-8 and } \\
\text { TIMP-2 }\end{array}$ & $\begin{array}{l}\text { MMP-8 and TIMP- } 2 \text { baseline concentrations in the } \\
\text { periodontal group were significantly higher than } \\
\text { those in the controls, but their concentrations } \\
\text { decreased after non-surgical therapy. }\end{array}$ \\
\hline $\begin{array}{l}\text { Prakasam et al. } \\
\text { (2014) [25] }\end{array}$ & $\begin{array}{l}\text { Moderate to } \\
\text { severe CP: } \\
40.80 \pm 10.07\end{array}$ & $18(9 / 9)$ & SRP & At 1 and 6 weeks & $\begin{array}{l}\text { Periodontally- } \\
\text { healthy: } \\
28.00 \pm 2.94\end{array}$ & $18(10 / 8)$ & Prophylaxis & $\begin{array}{l}\text { Approximately } \\
1-2 \text { weeks }\end{array}$ & UWS & $\begin{array}{l}\text { IL-4, IL-6, } \\
\text { IL-10, and } \\
\text { IL-17 }\end{array}$ & $\begin{array}{l}\text { IL-4 and IL-6 levels were significantly higher and } \\
\text { IL-10 and IL-17 levels were significantly lower in } \\
\text { chronic periodontitis patients in comparison with } \\
\text { healthy controls. } \\
\text { IL-4 levels were lower at } 6 \text { weeks post-SRP. IL-6 } \\
\text { and -17 levels did not change post-SRP. } \\
\text { IL-10 levels were significantly higher at } 6 \text { weeks } \\
\text { post-SRP. }\end{array}$ \\
\hline $\begin{array}{l}\text { Shyu et al. } \\
\text { (2015) [27] }\end{array}$ & $\begin{array}{l}\text { CP } \\
\text { Nonprogress } \\
\text { (NP) } \\
\text { treatment } \\
\text { group: } 61.5 \\
\text { Effective } \\
\text { treatment } \\
\text { (ET) group: } \\
\quad 56.0\end{array}$ & $\begin{array}{l}\text { NP group } 12 \\
\quad(5 / 7) \\
\text { ET group } 10 \\
\quad(4 / 6)\end{array}$ & Scaling & $\begin{array}{l}\text { Before and after } \\
\text { scaling }\end{array}$ & $\mathrm{N} / \mathrm{A}$ & $\mathrm{N} / \mathrm{A}$ & $\mathrm{N} / \mathrm{A}$ & $\mathrm{N} / \mathrm{A}$ & UWS & $\begin{array}{l}\text { IL- } 1 \alpha, 1 \beta, 6 \text {, } \\
\text { 8, TNF- } \alpha, \\
\text { and } \beta\end{array}$ & $\begin{array}{l}\text { Baseline IL- } 1 \alpha \text { and scaling-stimulated IL- } 1 \alpha \\
\text { showed a positive correlation }(\mathrm{r}=0.66 \text { and } \\
p<0.01) \text {. } \\
\text { Baseline IL-1 } \beta \text { and scaling-stimulated IL-1 } \beta \text { also } \\
\text { showed a positive correlation ( } \mathrm{r}=0.44 \text { and } \\
p=0.04) \text {. } \\
\text { Scaling-stimulated IL-6 was significantly } \\
\text { correlated with baseline IL-1 } \alpha \text {, IL-1 } 1 \beta \text {, IL-6, and } \\
\text { TNF- } \alpha \text {. } \\
\text { The differences in IL-1 } \alpha \text {, IL-6, and IL- } 8 \text { were } \\
\text { significantly higher in the ET group than in the } \\
\text { NP group. }\end{array}$ \\
\hline $\begin{array}{l}\text { Yang et al. } \\
\text { (2016) [21] }\end{array}$ & $\begin{array}{c}\text { CP: } 36.593 \pm \\
11.502\end{array}$ & $45(19 / 26)$ & SRP and OHI & $\begin{array}{l}\text { At baseline and } \\
\text { at } 1 \text { and } 3 \\
\text { months }\end{array}$ & $\begin{array}{l}\text { Periodontally- } \\
\text { healthy: } \\
35.827 \pm \\
8.012\end{array}$ & $47(19 / 28)$ & No treatment & $\mathrm{N} / \mathrm{A}$ & UWS & IL-17 & $\begin{array}{l}\text { IL-17 levels significantly reduced post-treatment } \\
\text { in comparison with the baseline (before } \\
\text { treatment) levels, especially at } 3 \text { months than at } \\
1 \text { month after treatment. }\end{array}$ \\
\hline $\begin{array}{l}\text { Öngöz et al. } \\
\text { (2017) [23] }\end{array}$ & $\begin{array}{l}\text { Mild to } \\
\text { moderate CP: } \\
39.44 \pm 3.15\end{array}$ & $27(14 / 13)$ & SRP & $\begin{array}{l}\text { Before and at } \\
4 \text { weeks }\end{array}$ & $\begin{array}{l}\text { Periodontally- } \\
\text { healthy: } \\
37.30 \pm 3.80\end{array}$ & $27(12 / 15)$ & No treatment & $\begin{array}{c}\text { Before } \\
\text { assessment }\end{array}$ & UWS & $\begin{array}{l}\text { IL-10, IL-32, } \\
\text { and TNF- } \alpha\end{array}$ & $\begin{array}{l}\text { TNF-a and IL-32 levels in the periodontitis group } \\
\text { were significantly lower after treatment compared } \\
\text { with the baseline levels, but IL-10 levels were } \\
\text { significantly higher. }\end{array}$ \\
\hline $\begin{array}{l}\text { Rangbulla et al. } \\
\text { (2017) [26] }\end{array}$ & $\begin{array}{l}\text { Moderate to } \\
\text { severe CP: } \\
\text { none }\end{array}$ & 30 (none) & SRP and OHI & $\begin{array}{l}\text { Before and } \\
12 \text { weeks }\end{array}$ & $\begin{array}{l}\text { Periodontally- } \\
\text { healthy: } \\
\text { none }\end{array}$ & 20 (none) & SRP and OHI & $\begin{array}{l}\text { Before and } \\
12 \text { weeks }\end{array}$ & UWS & $\begin{array}{l}\text { IL-1 } \beta \text { and } \\
\text { MMP-8 }\end{array}$ & $\begin{array}{l}\text { IL-1 } \beta \text { and MMP-8 levels in periodontitis patients } \\
\text { reduced significantly after oral prophylaxis, but } \\
\text { were still significantly higher than the baseline } \\
\text { values of controls. }\end{array}$ \\
\hline
\end{tabular}

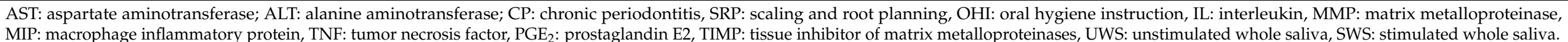


Depending on the stage of periodontal disease progression, the biomarkers in saliva with high linkage are IL-1 $\beta$ in the immunologic phase and MMP-8 in the inflammatory phase [26]. These two biomarkers demonstrated a high specify and sensitivity to predict collagen and alveolar bone loss.

\subsection{Quality Assessment}

Study quality as assessed by the ROBINS-I tool is summarized in Table 3. Among the 11 included studies, nine studies were graded as low-risk and two were graded as moderate-risk. All 11 studies met the ROBINS-I criteria for case definition and showed good representativeness (Table 3 ).

Table 3. Quality assessment of the included studies (ROBINS-I tool).

\begin{tabular}{|c|c|c|c|c|c|c|c|c|}
\hline Authors (Year) & $\begin{array}{l}\text { Confounding } \\
\text { Bias }\end{array}$ & $\begin{array}{l}\text { Selection } \\
\text { Bias }\end{array}$ & $\begin{array}{c}\text { Classification } \\
\text { Bias }\end{array}$ & $\begin{array}{c}\text { Intervention } \\
\text { Bias }\end{array}$ & $\begin{array}{l}\text { Missing Data } \\
\text { Bias }\end{array}$ & $\begin{array}{c}\text { Measurement } \\
\text { Bias }\end{array}$ & $\begin{array}{c}\text { Reporting } \\
\text { Bias }\end{array}$ & Overall Bias \\
\hline Yoshie et al. (2007) [34] & $\mathrm{PN}$ & $\mathrm{N}$ & $\mathrm{N}$ & $\mathrm{N}$ & $\mathrm{N}$ & $\mathrm{N}$ & $\mathrm{N}$ & Low \\
\hline Sexton et al. (2011) [22] & $\mathrm{N}$ & $\mathrm{N}$ & $\mathrm{N}$ & $\mathrm{PN}$ & UN & $\mathrm{N}$ & $\mathrm{N}$ & Low \\
\hline Kinney et al. (2011) [28] & $\mathrm{N}$ & $\mathrm{N}$ & $\mathrm{N}$ & PN & $\mathrm{N}$ & $\mathrm{N}$ & $\mathrm{N}$ & Low \\
\hline Kaushik et al. (2011) [24] & $\mathrm{N}$ & $\mathrm{N}$ & $\mathrm{N}$ & $\mathrm{PN}$ & $\mathrm{N}$ & $\mathrm{N}$ & $\mathrm{N}$ & Low \\
\hline Sánchez et al. (2013) [20] & UN & $\mathrm{N}$ & $\mathrm{N}$ & PY & UN & $\mathrm{N}$ & $\mathrm{N}$ & Moderate \\
\hline Meschiari et al. (2013) [29] & UN & $\mathrm{N}$ & $\mathrm{N}$ & $\mathrm{PN}$ & PN & $\mathrm{N}$ & $\mathrm{N}$ & Moderate \\
\hline Prakasam et al. (2014) [25] & PN & $\mathrm{N}$ & $\mathrm{N}$ & $\mathrm{N}$ & $\mathrm{N}$ & $\mathrm{N}$ & $\mathrm{N}$ & Low \\
\hline Shyu et al. (2015) [27] & $\mathrm{N}$ & $\mathrm{N}$ & $\mathrm{N}$ & $\mathrm{N}$ & $\mathrm{N}$ & $\mathrm{N}$ & $\mathrm{N}$ & Low \\
\hline Yang et al. (2016) [21] & $\mathrm{N}$ & $\mathrm{N}$ & $\mathrm{N}$ & $\mathrm{N}$ & $\mathrm{N}$ & $\mathrm{N}$ & PY & Low \\
\hline Öngöz et al. (2017) [23] & $\mathrm{N}$ & $\mathrm{N}$ & $\mathrm{N}$ & $\mathrm{PN}$ & $\mathrm{N}$ & $\mathrm{N}$ & $\mathrm{N}$ & Low \\
\hline Rangbulla et al. (2017) [26] & $\mathrm{PN}$ & $\mathrm{N}$ & $\mathrm{N}$ & $\mathrm{N}$ & UN & $\mathrm{N}$ & $\mathrm{N}$ & Low \\
\hline
\end{tabular}

Each domain is evaluated with one of the following: $\mathrm{PY}=$ "probably yes", $\mathrm{PN}=$ "probably no", $\mathrm{N}=$ "no", and UN = "unclear". The categories of overall bias for each study are low, moderate, serious, and critical risk of bias.

\subsection{Data Synthesis and Meta-Analysis}

The salivary cytokines identified from each independent study assessing both periodontitis patients and healthy controls are summarized in Table 2. Although the levels of IL-1 $\beta$ and MMP-8 and MMP-9 were presented in seven of the 11 articles, a meta-analysis was performed using the quantitative values for IL-1 $\beta$ and MMP-8 presented in the studies by Rangbulla et al. [26] and Kinney et al. [28] Except for these two studies, the levels of IL-1 $\beta$ and MMP-8 were presented as percentages or not quantified in the other studies. Since Kinney et al. did not include quantitative values in the original article, we requested the row data from the corresponding author, which was used for meta-analysis.

The pooled SMD of IL-1 $\beta$ was -1.04 [95\% CI: $-6.75,4.67]$ with the forest plot drawn in Figure 2. For heterogeneity testing, the chi-square value was $64.31(p<0.0001)$, and $I^{2}$ (variation in SMD attributable to heterogeneity) was $98 \%$. Thus, the variability in the difference between periodontitis patients and healthy controls was not significant.

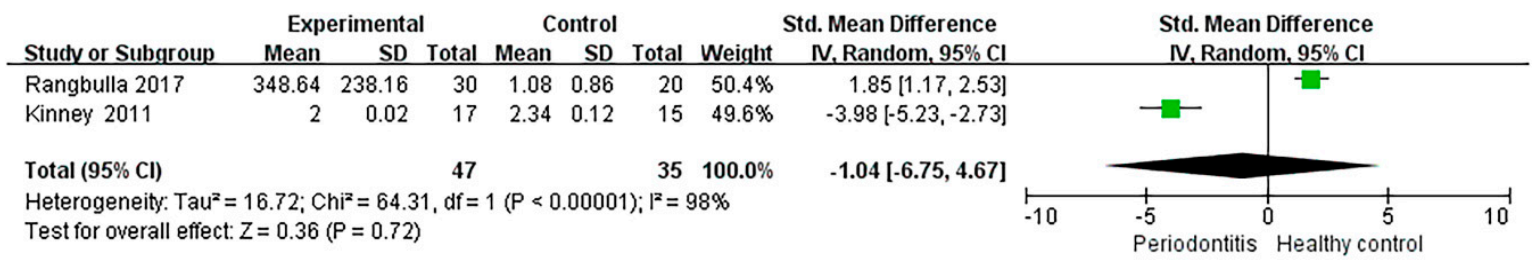

Figure 2. Effects on salivary IL-1 $\beta$ after non-periodontal surgery therapy. Note: green color, random effect interval in each study; black, total effect.

The pooled SMD of MMP-8 was 35.90 (95\% CI: $-31.52,103.33)$ with the forest plot drawn in Figure 3. For heterogeneity testing, the chi-square value was $52.62(p<0.0001)$, and $I^{2}$ (variation in SMD attributable to heterogeneity) was $98 \%$. Thus, the variability in difference between periodontitis patients and healthy controls was not significant. 


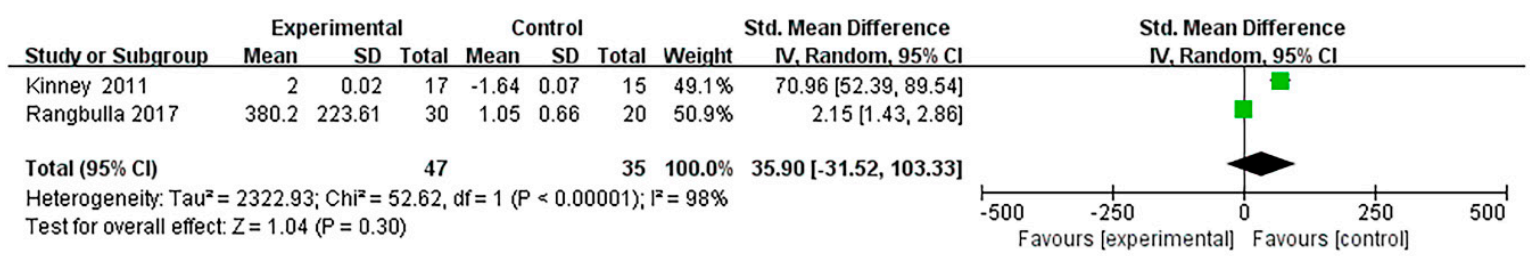

Figure 3. Effects on salivary MMP-8 after non-periodontal surgery therapy. Note: green color, random effect interval in each study; black, total effect.

\section{Discussion}

Dental professionals meet patients who are on the verge of losing a large number of teeth. The oral condition of the patients makes both the dental professionals and the patient very unfortunate. In order to prevent the condition, it is important to visit the dentist regularly for examinations and accurate diagnosis. For accurate diagnosis, periodontists conduct radiological and hand-instrument examinations. However, the clinical diagnosis by hand instrument examination is a time-consuming and difficult to both dental professionals and patients because all teeth must be assessed and recorded. Radiological examination may result in undiagnosed areas due to overlapping structures. Although these methods are generally used for clinical diagnosis of periodontal disease, it has the disadvantages of providing past disease and limited information on the progress of future periodontal disease. Therefore, a test kit for identifying bacteria and a system for testing for genetic factors related to periodontal disease has been reported. These new examination methods are difficult to alternate radiographic and hand-instrument examination, but their necessity is increasing in diagnostic examinations.

During periodontal disease, host inflammatory cells are recruited, and inflammatory cytokines, such as IL-1 $\beta$, IL-6, and TNF- $\alpha$, are released from fibroblasts, macrophages, connective tissue, and junctional epithelial cells. Then host-derived enzymes, MMP-8, MMP-9, and calprotectin are released by PMNs and osteoclasts, leading to connective tissue and alveolar bone degradation [28].

Various biomarkers in saliva have been proposed as candidates for the diagnosis of periodontal disease. Bacterial factors and inflammatory responses by cytokines, chemokines, and various factors that can cause periodontal disease have been identified at the saliva level. Therefor this meta-analysis systematically evaluated the salivary IL- $1 \beta$ and MMP-8 levels after SRP treatments in two independent studies, and the systematic review investigated the available evidence related to the differences in salivary biomarkers after non-surgical periodontal treatment. To the best of our knowledge, this is the first systematic review and meta-analysis to address these objectives. The main finding of the systematic review of 11 studies was that the inflammatory cytokines and enzymes used as salivary biomarkers were IL- $1 \alpha$, IL-1 $\beta$, IL-4, IL-6, IL-8, IL-10, IL-17, and IL-32, TNF- $\alpha$, TNF- $\beta$, PGE 2 , MMP-8, MMP-9, MIP- $1 \alpha$, and TIMP-2. IL-1 $\beta$, TNF- $\alpha$, MMP-8, and MMP-9 were the most commonly used salivary biomarkers used to identify the changes after SRP. The results of the meta-analysis confirmed that salivary IL- $1 \beta$ and MMP-8 levels were not significantly different before and after SRP treatment.

A previous study reported that among the salivary biomarkers, IL-1 $\beta$, MMP-8, MMP-9, and OPG demonstrated the highest correlation with disease status [39]. Further, the use of multiple time-points with two-month intervals for assessment of saliva biomarkers allows for an improved understanding of biomarker fluctuations over time. In this review, most studies collected clinical data and saliva samples once at one or three months after SRP, and several studies obtained measurements twice at one and three months. Various regenerative surgical modalities have been suggested and examined for the regeneration of periodontal specific tissues: alveolar bone, cementum, periodontal ligament, and gingiva. These studies assessed the recovery of the alveolar bone or periodontal tissue after four or eight weeks to verify the degree of healing [40]. 
Using a meta-analytical approach, a previous study found that MMP-8, MMP-9, IL-1 $\beta$, IL-6, and $\mathrm{Hb}$ were salivary biomarkers with good capability to detect periodontitis in systemically healthy subjects. MMP- 8 and IL-1 $\beta$ are the most researched biomarkers in related researches, both showing clinically fair effectiveness for the diagnosis of periodontitis [41]. In this study, these two markers were identified most frequently among 11 studies.

IL- $1 \beta$ is a prototype "multifunctional" proinflammatory cytokine that plays a major role in acute and chronic inflammation [42]. Fine et al. longitudinally evaluated periodontal disease progression in children at risk for aggressive periodontitis and reported that IL-1 $\beta$ demonstrated a high specificity and sensitivity to predict alveolar bone loss [43]. IL-1 $\beta$ stimulated endothelial cells to induce selectins, which facilitate recruitment of leukocytes, activate macrophage IL-1 production, stimulate production of inflammatory mediators (e.g., $\mathrm{PGE}_{2}$ ), cause MMP expression, enhance osteoclast formation and activity, stimulate the apoptosis of matrix-producing cells leading to inflammation, connective tissue breakdown, bone loss, and limited repair of periodontium [44].

MMPs are proteolytic enzymes belonging to the zinc protease superfamily and are involved in physiological degradation of extracellular matrix proteins and basement membranes. They can be categorized into several groups [45]. Salivary biomarkers, specifically MMP-8, MMP-9, OPG, and IL-1 $\beta$, are present in low concentrations and can predict stability in $78 \%$ of individuals who are clinically stable during disease monitoring.

The pooled SMDs of salivary IL-1 $\beta$ and MMP- 8 were not significantly confirmed after SRP treatments. Although salivary changes were checked 4-16 weeks after SRP, no significant difference was found. This result may be attributable to the minimal changes in the salivary levels of IL-1 $\beta$ and MMP-8 presented in the study by Kinney et al. [28], which was included in this meta-analysis. A meta-analysis performed by Zhang et al. [46] reported that salivary MMP-8 levels were significantly higher in periodontitis patients than in healthy controls overall. On the other hand, no significant changes were observed in serum biomarker levels after non-surgical periodontal treatment in pregnant women with periodontitis [47]. Furthermore, analyses of serum biomarkers have been reported to yield inconsistent findings across individuals and were largely not sustainable [48]. A previous systematic review and meta-analysis indicated that MIP- $1 \alpha$ had excellent diagnostic accuracy while IL-1 $\beta$ and IL- 6 had acceptable diagnostic values. However, one study only evaluated the biomarkers considered to be excellent, which may reduce the robustness of the results [49]. As shown in this study, further studies are needed to determine the salivary biomarkers that can be used for the diagnosis of periodontal disease and confirmation of treatment effects. MMP-8 showed a significant difference between the treatment and control groups. However, there is a lack of studies investigating the changes in salivary biomarkers after SRP. Thus, a meta-analysis including more studies will be needed to identify significant differences.

IL-8 has a role as a major mediator of the inflammatory response and chemoattractant for neutrophils. However, in the studies included in this review, no significant differences were found before and after treatment [22,50]. Yang et al. [21] showed that IL-17 level was higher in chronic periodontitis group and was correlated with variation in the microbial parameters. IL-17 is a pro-inflammatory cytokine produced by T-helper 17 cells, which recruit neutrophils and macrophages to participate in and amplify inflammatory reaction [51].

The levels TNF- $\alpha$ and IL-32 in gingival crevicular fluid and saliva were higher in chronic periodontitis patients, and then after treatments, these two biomarkers decreased. However, the levels of IL-10 were lower in patients and the IL-10 levels were higher after treatments [23]. Previous studies demonstrated that TNF- $\alpha$ is one of the most influential cytokines and plays a key part in pathogenesis of several serious and persistent inflammatory ailments [52]. Moreover, IL-10 is the powerful anti-inflammatory cytokine and might also play an important role in the control and development of periodontal inflammation [53]. IL-32 is evaluated for one of the newest discoveries cytokine and has proinflammatory properties and is stimulated by activated T-lymphocytes and activated natural killer cells. In 
addition, IL-32 stimulates the production of osteoclasts, without the need for autonomous RANKL generation [54].

Meschiari et al. [29] reported that using zymography gelationlytic activity of MMP-9 forms may be related to lower local inflammation, represented by improvement of the clinical parameters. The reduction in biofilm formation by scaling leads to lower levels of pro-inflammatory cytokines [55]. The reduction in tissue degradation after PD treatment seems to be associated with decreased MMP-9 activity. However, there is no significant difference in MMP-9 activity before and after treatment [29].

In conclusion, no changes were observed in salivary IL- $1 \beta$ and MMP-8 levels after SRP in this meta-analysis. However, in the 11 studies included in this study, IL- $1 \beta$, MMP-8 and TNF- $\alpha$ in saliva were the most frequently observed biomarkers in periodontal disease patients compared to healthy controls. In addition, many studies have suggested the possibility of a point-of-care device using biomarkers in saliva. However, further interpretations based on these results should be performed with caution. The limitations of this study are as follows: each study included a small number of participants; not many studies investigated the changes in salivary biomarkers after SRP; the criteria for the diagnosis of periodontal disease were not identical among the included studies; and depending on the classification used, patient groups were divided into severe or mild periodontitis.

In summary, this systematic review shows that while salivary cytokine levels related to periodontal disease after treatment did show quantitative differences, the meta-analysis did not show significant differences. Thus, collection of saliva biomarkers could offer potential for the prediction of periodontal disease progression in large patient populations.

\section{Conclusions}

There were insufficient data to conduct a meta-analysis on the effect of non-surgical periodontal therapy on changes in salivary IL-1 $\beta$ and MMP-8 levels. The meta-analysis showed no statistically significant decrease or alterations in the levels of IL-1 $\beta$ and MMP-8 after non-surgical periodontal therapy between the treatment and healthy control groups. However, we confirmed that the inflammatory cytokines and enzymes used as salivary biomarkers were IL- $1 \alpha$, IL-1 $\beta$, IL-4, IL-6, IL-8, IL-10, IL-17, IL-32, TNF- $\alpha$, TNF- $\beta$, PGE2, MMP-8, MMP-9, MIP- $1 \alpha$, and TIMP-2, and that IL-1 $\beta$, TNF- $\alpha$, MMP-8, and MMP-9 were most commonly used salivary biomarkers to identify the changes after SRP, indicating the potential applicability of saliva for the diagnosis of periodontal disease.

Author Contributions: Conceptualization: J.-Y.K. and H.-N.K.; methodology: H.-N.K.; data curation: J.-Y.K.; writing—original draft preparation: J.-Y.K. and H.-N.K.; writing, reviewing, and editing: J.-Y.K. and H.-N.K.; visualization: J.-Y.K.; supervision: J.-Y.K. and H.-N.K.; project administration: J.-Y.K. and H.-N.K. All authors have read and agreed to the published version of the manuscript.

Funding: This work was supported by the National Research Foundation of Korea (NRF) and the grant was funded by the Korean government (MSIT) (no. NRF-2019R1G1A1100040).

Institutional Review Board Statement: Not applicable.

Informed Consent Statement: Not applicable.

Acknowledgments: We would like to thank the authors of studies included in this systematic review and meta-analysis for providing data.

Conflicts of Interest: The authors declare no conflict of interest.

\section{Abbreviations}

IL: interleukin; ILs: interleukins; MMP: matrix metalloproteinase; MMPs: matrix metalloproteinases; TNFs: tumor necrosis factors; SRP: scaling and root planning; OHI: oral hygiene instruction; $\mathrm{PGE}_{2}$ : prostaglandin $\mathrm{E}_{2}$; PRISMA: Preferred Reporting Items for Systematic Reviews and MetaAnalyses; MeSH: Medical Subject Heading; ROBINS-I: Risk of Bias in Nonrandomized Studies of Interventions; PICO: Population, intervention, comparison, and outcome; MD: mean difference; SMD: standardized mean difference; PD: pocket depth; CAL: clinical attachment loss; BOP: bleeding of probing; GI: gingival index; AST: aspartate aminotransferase; ALT: alanine aminotransferase; 
CP: chronic periodontitis; MIP: macrophage inflammatory protein; TIMP: tissue inhibitor of matrix metalloproteinase;, UWS: unstimulated whole saliva; SWS: stimulated whole saliva.

\section{References}

1. $\quad$ Eke, P.I.; Dye, B.A.; Wei, L.; Slade, G.D.; Thornton-Evans, G.O.; Borgnakke, W.S.; Taylor, G.W.; Page, R.C.; Beck, J.D.; Genco, R.J. Update on Prevalence of Periodontitis in Adults in the United States: NHANES 2009 to 2012. J. Periodontol. 2015, 86, 611-622. [CrossRef] [PubMed]

2. Eke, P.I.; Wei, L.; Borgnakke, W.S.; Thornton-Evans, G.; Zhang, X.; Lu, H.; McGuire, L.C.; Genco, R.J. Periodontitis prevalence in adults $\geq 65$ years of age, in the USA. Periodontology 2000, 72, 76-95. [CrossRef] [PubMed]

3. Centers for Disease Control and Prevention. Available online: https://www.cdc.gov/oralhealth/conditions/periodontal-disease. html (accessed on 10 November 2020).

4. Salminen, A.; Elisa Kopra, K.A.; Hyvärinen, K.; Paju, S.; Mäntylä, P.; Buhlin, K.; Nieminen, M.S.; Sinisalo, J.; Pussinen, P.J. Quantitative PCR analysis of salivary pathogen burden in periodontitis. Front. Cell. Infect. Microbiol. 2015, 5, 69. [CrossRef] [PubMed]

5. Jokstad, A. The 2018 AAP/EFP classification of periodontal diseases, a focus on "risks" as a faux ami and language gone on holiday. Clin. Exp. Dent. Res. 2019, 5, 449. [CrossRef]

6. Fortunato, L.; Bennardo, F.; Buffone, C.; Giudice, A. Is the application of platelet concentrates effective in the prevention and treatment of medication-related osteonecrosis of the jaw? A systematic review. J. Cranio-Maxillofacial Sur. 2020, 48, 268-285. [CrossRef]

7. Giannobile, W.V.; McDevitt, J.T.; Niedbala, R.S.; Malamud, D. Translational and clinical applications of salivary diagnostics. Adv. Dent. Res. 2011, 23, 375-380. [CrossRef]

8. Zhang, L.; Henson, B.S.; Camargo, P.M.; Wong, D.T. The clinical value of salivary biomarkers for periodontal disease. Periodontology 2000, 51, 25-37. [CrossRef]

9. Kaufman, E.; Lamster, I.B. Analysis of saliva for periodontal diagnosis. J. Clin. Periodontol. 2000, 27, 453-465. [CrossRef]

10. Isaza-Guzmán, D.M.; Cardona-Vélez, N.; Gaviria-Correa, D.E.; Martínez-Pabón, M.C.; Castaño-Granada, M.C.; Tobón-Arroyave, S.I. Association study between salivary levels of interferon (IFN)-gamma, interleukin (IL)-17, IL-21, and IL-22 with chronic periodontitis. Arch. Oral Biol. 2015, 60, 91-99. [CrossRef]

11. Cekici, A.; Kantarci, A.; Hasturk, H.; Van Dyke, T.E. Inflammatory and immune pathways in the pathogenesis of periodontal disease. Periodontology 2000 2014, 64, 57-80. [CrossRef]

12. Da Costa, T.A.; Silva, M.J.B.; Alves, P.M.; Chica, J.E.L.; Barcelos, E.Z.; Giani, M.A.A.; Garlet, G.P.; da Silva, J.S.; Rodrigues Júnior, V.; Rodrigues, D.B.R.; et al. Inflammation biomarkers of advanced disease in nongingival tissues of chronic periodontitis patients. Mediators Inflamm. 2015, 2015, 983782. [CrossRef] [PubMed]

13. Izadi Borujeni, S.; Mayer, M.; Eickholz, P. Activated matrix metalloproteinase-8 in saliva as diagnostic test for periodontal disease? A case-control study. Med. Microbiol. Immunol. 2015, 204, 665-672. [CrossRef] [PubMed]

14. Leppilahti, J.M.; Hernández-Ríos, P.A.; Gamonal, J.A.; Tervahartiala, T.; Brignardello-Petersen, R.; Mantyla, P.; Sorsa, T.; Hernández, M. Matrix metalloproteinases and myeloperoxidase in gingival crevicular fluid provide site-specific diagnostic value for chronic periodontitis. J. Clin. Periodontol. 2014, 41, 348-356. [CrossRef] [PubMed]

15. Leppilahti, J.M.; Sorsa, T.; Kallio, M.A.; Tervahartiala, T.; Emingil, G.; Han, B.; Mäntylä, P. The utility of gingival crevicular fluid matrix metalloproteinase-8 response patterns in prediction of site-level clinical treatment outcome. J. Periodontol. 2015, 86, 777-787. [CrossRef] [PubMed]

16. Marcaccini, A.M.; Meschiari, C.A.; Zuardi, L.R.; De Sousa, T.S.; Taba, M.; Teofilo, J.M.; Jacob-Ferreira, A.L.B.; Tanus-Santos, J.E.; Novaes, A.B.; Gerlach, R.F. Gingival crevicular fluid levels of MMP-8, MMP-9, TIMP-2, and MPO decrease after periodontal therapy. J. Clin. Periodontol. 2010, 37, 180-190. [CrossRef] [PubMed]

17. Sorsa, T.; Mäntylä, P.; Tervahartiala, T.; Pussinen, P.J.; Gamonal, J.; Hernandez, M. MMP activation in diagnostics of periodontitis and systemic inflammation. J. Clin. Periodontol. 2011, 38, 817-819. [CrossRef]

18. Booth, V.; Young, S.; Cruchley, A.; Taichman, N.S.; Paleolog, E. Vascular endothelial growth factor in human periodontal disease. J. Periodontal Res. 1998, 33, 491-499. [CrossRef]

19. Rudrakshi, C.; Srinivas, N.; Mehta, D.S. A comparative evaluation of hepatocyte growth factor levels in gingival crevicular fluid and saliva and its correlation with clinical parameters in patients with and without chronic periodontitis: A clinico-biochemical study. J. Indian Soc. Periodontol. 2011, 15, 147-151. [CrossRef]

20. Sánchez, G.A.; Miozza, V.A.; Delgado, A.; Busch, L. Salivary IL-1 $\beta$ and PGE2 as biomarkers of periodontal status, before and after periodontal treatment. J. Clin. Periodontol. 2013, 40, 1112-1117. [CrossRef]

21. Yang, X.; Chen, L.; Yaping, P. The influences of periodontal status and periodontal pathogen quantity on salivary 8hydroxydeoxyguanosine and interleukin-17 levels. J. Periodontol. 2016, 87, 591-600. [CrossRef]

22. Sexton, W.M.; Lin, Y.; Kryscio, R.J.; Dawson, D.R., 3rd; Ebersole, J.L.; Miller, C.S. Salivary biomarkers of periodontal disease in response to treatment. J. Clin. Periodontol. 2011, 38, 434-441. [CrossRef]

23. Öngöz Dede, F.; Balli, U.; Bozkurt Doğan, Ş.; Güven, B. Interleukin-32 levels in gingival crevicular fluid and saliva of patients with chronic periodontitis after periodontal treatment. J. Periodontal Res. 2017, 52, 397-407. [CrossRef] 
24. Kaushik, R.; Yeltiwar, R.K.; Pushpanshu, K. Salivary interleukin-1 $\beta$ levels in patients with chronic periodontitis before and after periodontal phase I therapy and healthy controls: A case-control study. J. Periodontol. 2011, 82, 1353-1359. [CrossRef] [PubMed]

25. Prakasam, S.; Srinivasan, M. Evaluation of salivary biomarker profiles following non-surgical management of chronic periodontitis. Oral Dis. 2014, 20, 171-177. [CrossRef] [PubMed]

26. Rangbulla, V.; Nirola, A.; Gupta, M.; Batra, P.; Gupta, M. Salivary IgA, Interleukin-1 $\beta$ and MMP-8 as Salivary Biomarkers in Chronic Periodontitis Patients. Chin. J. Dent. Res. 2017, 20, 43-51. [CrossRef]

27. Shyu, K.G.; Choy, C.S.; Wang, D.C.L.; Huang, W.C.; Chen, S.Y.; Chen, C.H.; Lin, C.T.; Chang, C.C.; Huang, Y.K. Change of scaling-induced proinflammatory cytokine on the clinical efficacy of periodontitis treatment. Sci. World J. 2015, $2015,289647$. [CrossRef] [PubMed]

28. Kinney, J.S.; Morelli, T.; Braun, T.; Ramseier, C.A.; Herr, A.E.; Sugai, J.V.; Shelburne, C.E.; Rayburn, L.A.; Singh, A.K.; Giannobile, W.V. Saliva/pathogen biomarker signatures and periodontal disease progression. J. Dent. Res. 2011, 90, 752-758. [CrossRef] [PubMed]

29. Meschiari, C.A.; Marcaccini, A.M.; Santos Moura, B.C.; Zuardi, L.R.; Tanus-Santos, J.E.; Gerlach, R.F. Salivary MMPs, TIMPs, and MPO levels in periodontal disease patients and controls. Clin. Chim. Acta 2013, 421, 140-146. [CrossRef] [PubMed]

30. Melguizo-Rodríguez, L.; Costela-Ruiz, V.J.; Manzano-Moreno, F.J.; Ruiz, C.; Illescas-Montes, R. Molecular Sciences Salivary Biomarkers and Their Application in the Diagnosis and Monitoring of the Most Common Oral Pathologies. Int. J. Mol. Sci. 2020, 21, 51-73. [CrossRef]

31. Liberati, A.; Altman, D.G.; Tetzlaff, J.; Mulrow, C.; Gøtzsche, P.C.; Ioannidis, J.P.A.; Clarke, M.; Devereaux, P.J.; Kleijnen, J.; Moher, D. The PRISMA Statement for Reporting Systematic Reviews and Meta-Analyses of Studies That Evaluate Health Care Interventions: Explanation and Elaboration. PLoS Med. 2009, 6, e1000100. [CrossRef]

32. Whiting, P.; Savović, J.; Higgins, J.P.; Caldwell, D.M.; Reeves, B.C.; Shea, B.; Davies, P.; Kleijnen, J.; Churchill, R. ROBIS: A new tool to assess risk of bias in systematic reviews was developed. J. Clin. Epidemiol. 2016, 69, 225-234. [CrossRef] [PubMed]

33. Reeves, B.C.; Deeks, J.J.; Higgins, J.P.; Shea, B.; Tugwell, P.; Wells, G.A. Including non-randomized studies on intervention effects. In Cochrane Handbook for Systematic Reviews of Interventions; Wiley: Hoboken, NJ, USA, 2019; pp. 595-620.

34. Yoshie, H.; Tai, H.; Kobayashi, T.; Oda-Gou, E.; Nomura, Y.; Numabe, Y.; Ito, K.; Kurihara, H.; Kamoi, K. Salivary enzyme levels after scaling and interleukin-1 genotypes in Japanese patients with chronic periodontitis. J. Periodontol. 2007, 78, 498-503. [CrossRef] [PubMed]

35. Todorovic, T.; Dozic, I.; Barrero, M.V.; Ljuskovic, B.; Pejovic, J.; Marjanovic, M.; Knezevic, M. Salivary enzymes and periodontal disease. Medicina Oral Patología Oral y Cirugía Bucal. Ed. Inglesa 2006, 11, 4.

36. Ersin Kalkan, R.; Öngöz Dede, F.; Gökmenoğlu, C.; Kara, C. Salivary fetuin-A, S100A12, and high-sensitivity C-reactive protein levels in periodontal diseases. Oral Dis. 2018, 24, 1554-1561. [CrossRef] [PubMed]

37. Kurgan, Ş.; Önder, C.; Altıngöz, S.M.; Bağış, N.; Uyanık, M.; Serdar, M.A.; Kantarcı, A. High sensitivity detection of salivary 8-hydroxy deoxyguanosine levels in patients with chronic periodontitis. J. Periodontal Res. 2015, 50, 766-774. [CrossRef] [PubMed]

38. Haigh, B.J.; Stewart, K.W.; Whelan, J.R.; Barnett, M.P.; Smolenski, G.A.; Wheeler, T.T. Alterations in the salivary proteome associated with periodontitis. J. Clin. Periodontol. 2010, 37, 241-247. [CrossRef]

39. Ramseier, C.A.; Kinney, J.S.; Herr, A.E.; Braun, T.; Sugai, J.V.; Shelburne, C.A.; Rayburn, L.A.; Tran, H.M.; Singh, A.K.; Giannobile, W. V Identification of pathogen and host-response markers correlated with periodontal disease. J. Periodontol. 2009, 80, 436-446. [CrossRef]

40. Polimeni, G.; Xiropaidis, A.V.; Wikesjo, U.M.E. Biology and principles of periodontal wound healing/regeneration. Periodontology 2000 2006, 41, 30-47. [CrossRef]

41. Arias-Bujanda, N.; Regueira-Iglesias, A.; Balsa-Castro, C.; Nibali, L.; Donos, N.; Tomás, I. Accuracy of single molecular biomarkers in saliva for the diagnosis of periodontitis: A systematic review and meta-analysis. J. Clin. Periodontol. 2020, 47, 2-18. [CrossRef]

42. Miller, C.S.; King, C.P.J.; Langub, M.C.; Kryscio, R.J.; Thomas, M. V Salivary biomarkers of existing periodontal disease: A cross-sectional study. J. Am. Dent. Assoc. 2006, 137, 322-329. [CrossRef]

43. Fine, D.H.; Markowitz, K.; Furgang, D.; Fairlie, K.; Ferrandiz, J.; Nasri, C.; McKiernan, M.; Donnelly, R.; Gunsolley, J. Macrophage inflammatory protein-1 $\alpha$ : A salivary biomarker of bone loss in a longitudinal cohort study of children at risk for aggressive periodontal disease? J. Periodontol. 2009, 80, 106-113. [CrossRef] [PubMed]

44. Cochran, D.D.T.G.D. The Contribution of Interleukin-1 and Tumor Necrosis Factor to Periodontal Tissue Destruction; Wiley: Hoboken, NJ, USA, 2003; Volume 74, pp. 391-401.

45. Franco, C.; Patricia, H.-R.; Timo, S.; Claudia, B.; Marcela, H. Matrix metalloproteinases as regulators of periodontal inflammation. Int. J. Mol. Sci. 2017, 18, 240. [CrossRef] [PubMed]

46. Zhang, L.; Li, X.; Yan, H.; Huang, L. Salivary matrix metalloproteinase (MMP)-8 as a biomarker for periodontitis: A PRISMAcompliant systematic review and meta-analysis. Medicine 2018, 97, e9642. [CrossRef] [PubMed]

47. Michalowicz, B.S.; Novak, M.J.; Hodges, J.S.; DiAngelis, A.; Buchanan, W.; Papapanou, P.N.; Mitchell, D.A.; Ferguson, J.E.; Lupo, V.; Bofill, J.; et al. Serum inflammatory mediators in pregnancy: Changes after periodontal treatment and association with pregnancy outcomes. J. Periodontol. 2009, 80, 1731-1741. [CrossRef]

48. Behle, J.H.; Sedaghatfar, M.H.; Demmer, R.T.; Wolf, D.L.; Celenti, R.; Kebschull, M.; Belusko, P.B.; Herrera-Abreu, M.; Lalla, E.; Papapanou, P.N. Heterogeneity of systemic inflammatory responses to periodontal therapy. J. Clin. Periodontol. 2009, 36, 287-294. [CrossRef] 
49. De Lima, C.L.; Acevedo, A.C.; Grisi, D.C.; Taba, M.; Guerra, E.; De Luca Canto, G. Host-derived salivary biomarkers in diagnosing periodontal disease: Systematic review and meta-analysis. J. Clin. Periodontol. 2016, 43, 492-502. [CrossRef]

50. Zwahlen, R.; Walz, A.; Rot, A. In vitro and in vivo activity and pathophysiology of human interleukin-8 and related peptides. Academic Press. Int. Rev. Exp. Pathol. 1993, 34, 27-42.

51. Cheng, W.C.; Hughes, F.J.; Taams, L.S. The presence, function and regulation of IL-17 and Th17 cells in periodontitis. J. Clin. Periodontol. 2014, 41, 541-549. [CrossRef]

52. Frodge, B.D.; Ebersole, J.L.; Kryscio, R.J.; Thomas, M.V.; Miller, C.S. Bone remodeling biomarkers of periodontal disease in saliva. J. Periodontol. 2008, 79, 1913-1919. [CrossRef]

53. Goutoudi, P.; Diza, E.; Arvanitidou, M. Effect of periodontal therapy on crevicular fluid interleukin- $1 \beta$ and interleukin-10 levels in chronic periodontitis. J. Dent. 2004, 32, 511-520. [CrossRef]

54. Moon, Y.M.; Yoon, B.Y.; Her, Y.M.; Oh, H.J.; Lee, J.S.; Kim, K.W.; Lee, S.J.; Woo, Y.J.; Park, K.S.; Park, S.H.; et al. IL-32 and IL-17 interact and have the potential to aggravate osteoclastogenesis in rheumatoid arthritis. Arthritis Res. Ther. 2012, 14, R246. [CrossRef] [PubMed]

55. Miller, C.S.; Foley, J.D.; Bailey, A.L.; Campell, C.L.; Humphries, R.L.; Christodoulides, N.; Redding, S.W. Current developments in salivary diagnostics. Biomark. Med. 2010, 4, 171-189. [CrossRef] [PubMed] 